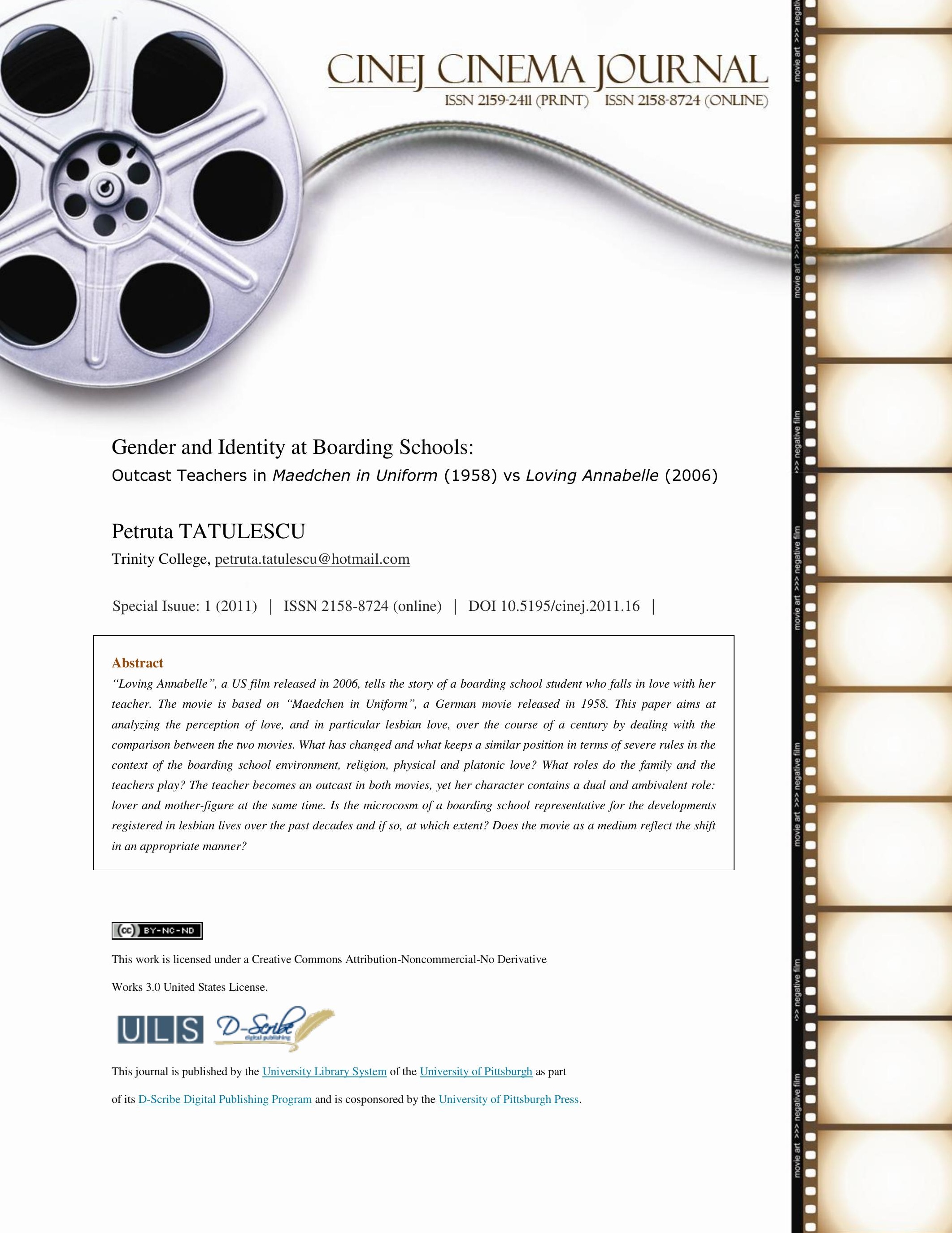




\section{Gender and Identity at Boarding Schools: Outcast Teachers in Maedchen in Uniform (1958) vs Loving Annabelle (2006)}

\section{Introduction}

This article compares the two movies from a scientific literary perspective, focusing on the narrative, text, dialogue and plot. Although incorporating main ideas of the feminist movement, the article is not an exercise in gender studies, but it rather focuses on a literary approach. This article is structured as follows: an introduction to the life at the boarding school that comprises a concise analysis of the outer setting, followed up by a look at the conflict and the inner setting. The religious element in the two movies is followed by remarks on family relations. This section concludes with a subchapter on teachers. Subsequently the focus turns to the second major topic of this article, which deals with sex, love and lesbian lives. The analysis of the titles and DVD covers concludes this article.

\section{Boarding schools}

The boarding school environment is coined by discipline in Mädchen in Uniform; this is reflected in multi-facetted ways. The movie was filmed in 1958, however, the plot is set in Prussia in 1910. Almost a century later the boarding school environment in Loving Annabelle is marked by rebellious students and an atmosphere of suspense and sexual attraction between the teacher and the student. The weather in the American boarding school is always sunny and clear, except for the last - and also ominous - night, when it is raining; in Mädchen in Uniform the entire setting is grey. The same applies to the uniforms: the girls at the German boarding school wear long, grey uniforms; almost half a century later the girls wear short tartan skirts and white shirts. However, this might have been influenced by the weather in the respective geographical area as well. Mädchen in Uniform is dominated by a grey note that is to be found in the uniforms, the building, and the weather. In Loving Annabelle there is more color - the blouses are white, however, the girls wear colored tartan skirts. In one of the last scenes of the movie, i. e. when Mother Immaculata enters Simone's room and catches her and Annabelle getting dressed, both of them are wearing bright red clothes.

The strict discipline at the German boarding school at the beginning of the $20^{\text {th }}$ century involves physical work: the girls must work in the schools tailoring; the superior says (minute 44:54): "Always fresh and lively. No shame in work, it ennobles." In the German boarding school the girls are noble, however, either orphaned or, in one way or the other, unwanted by their families. Their parents treat them in a very harsh manner: first and foremost by sending them to boarding school and also in a direct and rather harsh address through the words in their letters: "I shouldn't lose heart, writes mother. The fatherland needs people of iron. I don't want to be of iron." (minute 42:35). In the American boarding school the girls belong to some kind of material royalty: Annabelle's mum is a senator, Cat's father is a rock star. In this respect little seems to have changed - boarding schools remain places for the elite. However, Annabelle previously got expelled from two other schools - thus the boarding school can be regarded as a correctional institution to some extent. While in Mädchen in Uniform the girls belong to the noble elite, in Loving Annabelle they are part of the monetary elite. This is possibly a reflection of the definition of elite in the two countries and the respective times as well. 
The cast and characters in Mädchen in Uniform does not include a single man; the girls are completely isolated from the outside world. They grow up amidst other girls, their teachers are all female and even the personnel of the boarding school (e. g. the kitchen personnel, the cleaning lady) are female. Not so in Loving Annabelle: the Catholic priest has three short appearances, Simone's boy-friend plays in a few scenes (in which his character is shown in strong contrast to Annabelle), and Simone and her boyfriend go out with a married couple. [- however, while they are out, Simone is looking at two girls that seem to be on a date in the same place rather than concentrate on the conversation.]

The two dorms differ fundamentally. While in the 50es the girls sleep in a large hall with about 10 beds, in Loving Annabelle they have a more private room with just 4 beds. Privacy registers a large shift in the course of the century. Life at both boarding schools bears a violent note: in both movies the girls get in violent fights, there are beatings taking place on the floor and on the bed. There is a Sex \& Drugs \& Rock'n'roll component in Loving Annabelle - which is typical of contemporary depiction of life at boarding schools: the sex is omnipresent, the girls drink alcohol and smoke pot, and Annabelle plays in a band; she sings a song at the school dance she wrote for Simone. In the $20^{\text {th }}$ minute of Mädchen in Uniform the girls talk about not sending their own children to boarding school. Surprisingly, the issue is not addressed at all in Loving Annabelle, where the setting of the boarding school itself is not addressed much at all.

Annabelle tells Simone that she is a great teacher, but she would be a brilliant photographer. In Mädchen in Uniform having a career is seen as an alternative unless you get married (minute 27). You become a teacher only if you cannot find a husband. One of the mothers says: "I treat my daughter like my mother treated me. First the convent, then marriage, nothing in between." (minute 54). The superior replies to this comment by saying: "Just like our principles: children, church, kitchen!" (minute 54: 52).

The atmosphere at the boarding school in Mädchen in Uniform is coined by discipline. This fact is reflected in multifarious ways: the interaction between students and teachers, the uniforms, and last but not least by slogans written on the school walls: "Wie die Zucht, so die Frucht" - "Like breed, like fruit". "Der Mensch ist nicht auf der Welt, um glücklich zu sein, sondern um seine Pflicht zu tun. Bismarck" - "We're not put on this earth to be happy, but to do our duty". "Wir sind hier, um zu werden, nicht um zu sein." - "We are here to become, not to be" (translations into English by the author). One of the girls working in the kitchen warns one of her colleagues to watch out or she might get fired, because "You're too nice to the kids".

Classes are obviously part of the curriculum in both boarding schools (there is an English and a French teacher in Mädchen in Uniform), however, only Loving Annabelle shows scenes from literature class. One gets the impression that the boarding school in Mädchen in Uniform is only about discipline and work. The main character, Manuela von Meinhardis, while settling in, is not even allowed to join the choir and sing because she is supposed to get moving - "Don't stall" is what she is being told. She must turn in everything she has brought with her from home, including chocolates, all her own clothes and her diary. Her belongings get locked up in a closet. She is giving up her own identity in a lot of ways. [She later receives an undershirt from her beloved teacher as a present, because her own undershirt is too old and couldn't get fixed again. This could be interpreted as redeemed identity. However, Manuela interprets it as a sign of affection from her teacher.] She bundled her long hair in a braid, however, she is drawn attention that the braid is not tight enough. Life at this boarding house is coined by very severe discipline; the tone is strict and austere. The girls are marching, not walking through the yard. "The rules are the rules" is what even Ms. von Bernburg, the beloved and mild-hearted teacher, states. The aunt that takes Manuela to the boarding school insists on an austere education for her niece. 
The degree of austerity has notably changed during the years between the release of the two movies. In 2006 Annabelle is wearing a nose piercing she is not taking off, although summoned at multiple times; she has wildly dyed hair, a tattoo with a Buddhist sign clearly visible on the upper side of her wrist and she is wearing Buddhist beads. Furthermore she is smoking even before getting admitted into the building and all the way throughout the movie.

Both movies show activities that convey the interest in the arts: the students play Romeo and Julia in Mädchen in Uniform, Simone is interested in photography, and Annabelle writes songs and plays the guitar. Both boarding schools are Catholic institutions and have crucifixes on the walls. I assume that these two movies are so similar when it comes to religion because we are comparing Germany in the middle of the $20^{\text {th }}$ century and contemporary US. The look at the strict Catholic education is impossible to imagine in modern Germany, a more than secularized state. The boarding schools that still exist in Germany are based on the principle of elite and have very little to do with religious education. Actually the American boarding school in 2006 seems to be more bigot than the German one almost half a century earlier; the American girls even pray before meals. The German girls sing at times, however, that is as far as it gets. Simone's inner life is obviously influenced by religion - after Annabelle tried to kiss her in the $34^{\text {th }}$ minute but was rejected by Simone, she goes to the chapel and prays (minute 35). It is interesting to notice the Buddhist signs present in the movie in form of Annabelle's tattoo and her beads. Seen as a fetish of love, the beads are the present Annabelle got from the first woman she loved. At the end of the movie she passes them on to Simone. The beads are a fetish of love with a religious touch.

It is a major trait of boarding school stories that families and parents play only a marginal role at best. They might be completely absent. This is in contrast to stories taking place in schools, in which the kids divide their time between family and school. Teachers are dominant. There is a major shift in the image of the teacher over time: while very strict and austere in earlier days, the teachers are seen as friends and equals nowadays. In Mädchen in Uniform the beloved teacher Elisabeth von Bernburg is an exception from the average teacher at the boarding school when it comes to being mild-hearted; this is clearly reflected by her position in comparison with Fräulein von Racket, a vindictive colleague that would find any reason to punish the pupils. In Loving Annabelle the teacher, Simone Bradley, is weaker than her students at times, who on the whole display very strong characters and stubbornness. Regarding Simone, it is interesting to look at the onomastics - Simone sounds like Simone de Beauvoir; the name originates from the Hebrew Shim'on that means "hearing" and "understanding".

The teachers in Mädchen in Uniform wear long, grey severe looking clothes. Their dresses do not differ much from the students' dresses. In Loving Annabelle Simone usually wears pants and a white shirt resembling her students' shirts.

In an extrapolative interpretation manner it can be assumed that Manuela, the main character of Mädchen in Uniform, who is an orphan, seeks replacement for her beloved mother. She states that her aunt is "cold and far away, like the moon". Annabelle seems just as much of an orphan: she has already been expelled from two schools; this is why she is sent to this boarding school. It seems she might have been sent to boarding school, away from home and her family, also in order to keep her away from her mother's career and from endangering her mother's image through her inconvenient attitude. When she refuses to obey the strict dress code of the boarding school by not taking off her Buddhist beads and refusing to wear the rosary, the institute director, Mother Immaculata replies: "Your mother informs me that if you do not comply you'll be sent to military school."

Significantly, the Superior is an austere figure in both movies: while in Mädchen in Uniform she is a tyrannical, incredibly stingy old maid that is not even giving the girls enough food, she is actually portrayed as closer to the earthly world in Loving Annabelle because she is Simone Bradley's aunt. 
In Mädchen in Uniform the superior is a discipline fanatic, she completely dismisses new pedagogical approaches. She states: "I am not a believer in a child's rights to be an individual. These newfangled theories have no place in this institution. Not as long as I'm around. It's no coincidence that the door of this convent is covered in iron. This is a citadel." (minute 32: 46).

The word exchange between the Superior and Ms. Racket on one hand and the mild-hearted Ms. von Bernburg on the other hand is very descriptive of the pedagogical approach practiced at this boarding school and typifies the beginning of the $20^{\text {th }}$ century (minute 76 ):

Superior: "You grossly violated my request to be more distant."

Ms. Von Bernburg: "I am distant, when necessary."

Ms. Racket (who does not like Fräulein von Bernburg, the beloved teacher): "And what about Meinhardis? Compassion for her is too much. Absolutely inadmissible!"

Ms. Von Bernburg: "That's not for you to judge. You only issue commands, while I try to educate the girls."

Ms. Racket: "Which leads to behaviour such as Meinhardis's?"

Ms. von Bernburg: "You are overstepping your authority."

Superior: "One thing's for certain, Manuela von Meinhardis has developed an unhealthy fascination with you. I'd send her away, but that's not on because of the Princess. Whatever! She's to remain in the isolation room for now. And I don't want you to speak to her."

Ms. von Bernburg: "Sr. Superior...!"

Superior: "End of story!"

However, the first impression is dismissed by the plot: the austere superior in Mädchen in Uniform actually admits her mistake when she realizes Manuela is only searching for warmth, care and feelings; as a consequence she is asking Ms. von Bernburg to stay, which can be seen as conceding her mistakes and a correction in the nick of time. Mother Immaculata, the principal in Loving Annabelle, is more tyrannical at a subtle level: when Simone Bradley asks to send Annabelle to a different dorm because she cannot control her, Mother Immaculata states she should break her personality, like she had once done with Simone. Mother Immaculata is the one to catch Simone and Annabelle red-handed and as a consequence she fires Simone and tells her to leave the institution. She proves to be more draconic after all; she is not admitting any mistakes and simply controls and punishes the people around her.

The most consequential comparison when it comes to pedagogues is reflected in the strong contrast between the two main teacher characters of the respective movie. In my opinion, the comparison defines a paradigm shift in the vocational perception in the course of a century. Ms. von Bernburg is a teacher at heart that is more interested in making the pupils happy and following her pedagogical calling. She states (minute 32:43): "I think it is possible to be both: authoritative and friendly." She tells the superior she has not felt well in this particular institution from the very beginning; but as she saw only frightened kids around she decided to stay and help. Moreover, she resolves to leave the boarding school when she realizes that Manuela has fallen in love with her. Her motivation - in her own words - is that she does not want to hamper Manuela's development and she 
states she is confident the student will find her own way. Ms. von Bernburg is a professional at heart not ready to compromise when it comes to her vocation. She is depicted as a teacher, not as a woman.

Simone Bradley is a brilliant teacher and she enjoys her profession, however, she is shown more as a person in the movie: she is obviously confused by her feelings for Annabelle (especially underlined in the $57^{\text {th }}$ minute) and it takes her a while to give in to her feelings. At the end of the movie she is the one getting expelled from boarding school. It remains unclear if Annabelle can stay or must leave as well.

\section{Sex, love and lesbian lives}

Although Ms. von Bernburg and Manuela kiss in the $40^{\text {th }}$ minute of the movie, the relationship between the two is not coined by physical attraction but a rather discreet understanding. It is very hard to tell what Ms. Bernburg feels for Manuela: she certainly likes her, but there are no proofs that she feels more than that for her student. Her decision to go away because she does not want to detriment Manuela's development can be seen as an act of cowardice or as a noble gesture. She is somewhat strict to Manuela (minute 78) and sends her away. Manuela is attempting to commit suicide afterwards.

Not so in Loving Annabelle: the teacher and the student are very distinctly drawn to each other from the very beginning. The student rebels in order to draw the teacher's attention. Annabelle's body language signals she is interested in Simone. Annabelle attempts to kiss Simone in the $34^{\text {th }}$ minute but fails.

The chemistry between the two is underlined by the contrastive representation of the relationship between Simone and her boy-friend: there is no chemistry between the two; he wants to move in with her; Simone claims she wants more time; the sex scene between them in the $29^{\text {th }}$ minute is the exact opposite of steamy.

There is an attempt from Annabelle's side to pet Simone's hand during a movie, however, Simone does not allow the petting (minute 52). Although Annabelle and Simone kiss much later than in Mädchen in Uniform, i. e. in the $62^{\text {nd }}$ minute, the scene is immediately followed up by passionate sex between them. The sex scene is very revealing in an audio-visual way: there is a lot of moaning involved and the act is not only insinuated.

Not surprisingly, there is no reference to sex or being gay in Mädchen in Uniform. Not so in Loving Annabelle: orgasms are the subject of the literature class (minute 11), when one of Rilke's poems is interpreted as describing climatic sex; Walt Whitman's being gay is an issue in class as well. Cat, Annabelle's roommate, outs herself as being bi-sexual. Even the word choice revolves around the topic: "This is so gay" is one of Annabelle's comments while playing "I've never" with her roommates (minute 15). Sex and being gay is addressed openly and for multiple times in the discourse.

Although in Mädchen in Uniform there is no sexual intercourse, Manuela states - in an inebriated state in front of the entire boarding school that she loves her teacher. She earns spatial isolation (she is taken to the "isolation wing") and a ban on communication (her classmates are forbidden to talk to her) for her behavior. She would have been expelled, but since she is the princess's protégé she stays at the boarding school.

Simone and Annabelle are much more discreet about proclaiming their feelings in front of the other characters. It is not till the $69^{\text {th }}$ minute (which is shortly before the end), that Simone states in front of the Superior: "I don't expect you to understand, but I love her." 


\section{Conclusion}

In the middle of the $20^{\text {th }}$ century the discourse revolves around love and feelings, there is, however, little physical interaction involved in the plot. At the beginning of the $21^{\text {st }}$ century there is an abundance of sex talk, the discourse is littered with erotic terms. Kissing and sexual intercourse are happening frequently and are shown regularly. However, there is very little being said about feelings, and love is more or less external to the plot - its manifestation has something final to it: it either involves the loss by death (Simone's girl-friend), loss because of moving away (Annabelle's first love) or separation because it is not part of a socially accepted relationship (Annabelle and Simone).

In Mädchen in Uniform there is no real lesbian environment and thus no lesbian life. The girls warn Manuela at her admission to the boarding school that everyone falls in love with the teacher Ms. von Bernburg. However, the kiss between the two remains an exception; lesbian life takes place at a platonic level if at all.

In Loving Annabelle the teacher and the student are perceptibly drawn to each other. Annabelle admits to Simone in the $12^{\text {th }}$ minute that she is intrigued by her. There is more bonding between them than in Mädchen in Uniform - Annabelle must stay at the boarding school over spring break and during this time she smokes with Simone and they drive together to Simone's beach house. However, they have their only physical experience right before getting caught and expelled from boarding school. The rigid rules confine them to living a lesbian life only outside of the boarding school environment - a microcosm that stands for a society governed by rules - and ultimately outside of the socio-accepted norms.

Already in the $15^{\text {th }}$ minute of the movie there is Annabelle's outing in front of her roommates. Her roommates react in a positive way to her outing: one of them says "Wow!" and Cat, the tomboy, says "Finally a lesbian!" In the $22^{\text {nd }}$ minute she outs in front of the teacher.

Although being gay is articulated as part of the discourse, it is not always addressed in a positive manner (minute 18:31). Cat, the tomboy passes Annabelle a note asking if she has a girl-friend. Annabelle writes back "Women suck!!" In a marginal scene (minute 31:31) Annabelle kisses Cat, her tomboyish self declared bisexual roommate. (Cat outed herself in the $28^{\text {th }}$ minute: "I am into men too.") Nevertheless, there is a more perceptible lesbian environment in Loving Annabelle: at the boarding school there was another lesbian student, however, she had graduated.

Outside of the boarding school, both, Simone and Annabelle have had same sex partners before: Annabelle says the first person she fell in love with was a girl that moved to Europe with her parents last year (minute 22:36); Simone's obvious love of her life was a girl that committed suicide a while ago.

Each movie features a female character that prompts the outcome of the plot: in Mädchen in Uniform it is one of Manuela's roommates who is also in love with the teacher and jealous of Manuela. She spies on the two and threatens Manuela to go to the Superior. However, it is Manuela who in an inebriated state outs her love for the teacher and she claims in front of everyone that she knows her feelings are being reciprocated. In Loving Annabelle it is Cat, the bisexual tomboy, who draws Mother Immaculata's attention that Simone and Annabelle are missing and prompts the superior to go to Simone's room, where she finds the two lovers getting dressed. However, Cat is not in love with the teacher (she confessed in the $28^{\text {th }}$ minute that she had a crush on Simone in her first grade), she is rather interested in Annabelle and jealous of the two. 


\section{Epilogue}

The title Mädchen in Uniform/ Girls in Uniform does not give away much about the movie, except for the fact that the movie is set at a boarding school and that it is about girls wearing uniforms. Loving Annabelle, on the other hand, clearly shows it is a love story. The boarding school is the setting; however, it seems secondary to a certain extent. In my opinion this marks the shift in attitudes when talking about feelings: while the first half of the $20^{\text {th }}$ century is dominated by the setting in media (e. g. Death on the Nile), in the second half of the century there is more interest in what is going on at a certain time and place - e. g. love, hate, war -, and the individual gains a tremendous importance - e. g. Annabelle, The Simpsons.

At the beginning of the $21^{\text {st }}$ century the movie and DVD industry has become much more plastic and show-offish: Simone and Annabelle are shown embracing on the front cover and in bed on the back cover. Manuela and Ms. von Bernburg are shown in a dark setting, possibly in order to convey their confusion, Manuela in an attempt to kiss her teacher. The back cover only shows black and white movie excerpts. When ordering the 2 DVDs from the German Amazon Mädchen in Uniform was delivered just like it is. Loving Annabelle, on the other hand, has an inlay called "Queer Cinema" featuring the general catalogue for fall 2009. It is obvious that Loving Annabelle is clearly targeted at a queer audience.

\section{References}

Loving Annabelle (2006). USA

Mädchen in Uniform (1958). Deutschland.

Petruta Tatulescu has been born and raised in Romania. She moved to Germany at the age of 19. After graduating from Heidelberg University she has been teaching English, German, Romanian and French, worked as a journalist, wrote and published a few literary pieces, gathered experience in corporate communications, marketing and operations.

While working on her $\mathrm{PhD}$ thesis on "Boarding Schools in German Literature" she was offered a position with Trinity College, Dublin. She moved to Ireland in September of 2010 and has been teaching German with the Department of Germanic Studies. Her PhD thesis is soon to be completed. 